\title{
肝臓に腫瘍性病変を有する腎細胞癌の検討
}

\author{
国立がんセンター病院泌尿器科 \\ 田中 良典 垣添 忠生 蔦巣 賢一 高井 計弘*
}

\section{ANALYSIS OF RENAL CELL CARCIONOMA WITH TUMOROUS LEGION IN THE LIVER}

\author{
Yoshinori Tanaka, Tadao Kakizoe, Ken-ichi Tobisu and Kazuhiro Takai* \\ Urology Division, National Cancer Center Hospital \\ *Japan Red Cross Medical Center
}

We presented 3 cases of renal cell carcinoma with hepatic lesion, for which it was difficult to make a diagnosis preoperatively.

The hepatic lesion was cavernous hemangioma of the liver, liver metastasis of renal cell carcinoma or hepatocellular carcinoma.

To discuss the strategy of treatment for liver metastasis of renal cell carcinoma at the time of nephrectomy, or in the follow-up period after nephrectomy, we reviewed the 188 cases of renal cell carcinoma which were nephrectomized from December, 1962 to June, 1988. At the time of nephrectomy, there was only 1 case that had concurrent liver metastasis. In 4 cases, liver metastasis was found at autopsy, and in 15 cases, in the follow-up period after nephrectomy.

We analysed these 15 cases and classified them into 2 groups. One was "early metastasis group", i.e., liver metastasis was found within 18 months after nephrectomy, and the other was "late metastasis group", i.e., liver metastasis detected more than 6 years after nephrectomy.

In the "early metastasis group", 2 lived 10 months or 57 months, but 5 died within 1 month after the appearance of liver metastasis. In the "late metastasis group", 4 of 7 lived more than 2 years after the appearance of liver metastasis and the median survival was 21 months. In both groups, when liver metastasis was found, there were metastases in multiple organs and the hepatic lesions were multiple.

Since patients with renal cell carcinoma rarely have liver metastasis at the time of diagnosis, in cases with hepatic lesions not confirmed to be benign, it should be resected simultaneoulsy. The appearance of liver metastasis in the follow-up period after nephrectomy means the end stage in the natural course of renal cell carcinoma. But in some cases of the "late metastasis group", with slow progression, surgical intervention for liver metastasis may be indicated.

要旨：国立がんセンターで経験した, 腎摘除術時に肝に腫瘍性病変を認めた 3 例の腎細胞癌の臨床経過 を呈示した. 肝病変は, それぞれ肝海綿状血管腫, 腎細胞癌の肝転移, および肝細胞癌であった。次に, 腎摘除術時または腎摘除術後の経過観察期間中に認める肝転移の治療方針を決定するために, 1962 年12 月から1988年 6 月までに腎摘除術を施行した188例の腎細胞癌のうち, 肝転移を有した 20 例を検討した. 腎摘除術時に発見されたのは 1 例のみで, 剖検時の発見が 4 例, 腎摘除術後の経過観察中に発見された のが15例であった。この 15 例は肝転移出現の時期により, 腎摘除術後 1 年 6 カ月以内に出現する早期群 と, 6 年以上経て出現する晚期群に分けられた。早期群 8 例のらち, 肝転移出現後 10 力 々 4 年 9 力月 生存した 2 例, 拈よび現在 2 カ月生存中の 1 例を除いた 5 例は, 肝転移出現後 1 カ月で死亡した。晚期 群 7 例のうち 4 例は肝転移出現後も 2 年以上生存し, 晚期群の平均生存期間は 21 月であった.

以上より，腎細胞癌の診断の時点で肝転移を有する可能性は低いが, 肝病変が良性であると確診され ない限りは肝病変も合併切除するべきであると思われた。 また, 腎摘除術後に出現する肝転移は, 腎細

*現日本赤十字社医療センター泌尿器科 
胞癌の自然経過の中で末期に出現する病態と思われ, 一般に積極的治療の対象とはなりにくいが, 晚期 群の中には外科的治療の適応となる場合もあると考えられた。

\section{緒言}

CT scan や超音波断層法の進歩により，腎細胞癌 (以下腎癌)の術前病期診断はかなり正確に行兄るよう になった ${ }^{12)}$. しかしながら，肝に同時に腫瘍性病変を 有する場合に，特に右腎癌の場合には，それが肝転移 なのか，直接浸潤なのか，あるいは肝に固有の病变な のかの鑑別が困難なことがある。また，肝転移が起こ るとしても，それがいつ，どのような形で出現するの かを知ることは，術前診断や治療方針決定の一助とな ろう．以上の観点から，当院で経験した術前画像診断 上の鑑別が困難であった代表的な 3 例を呈示するとと むに, 当院の腎癌の肝転移例に対し, その出現様式・ 時期について解析を行ない，あわせて肝転移に対する 治療方針に関して考察を加えた。

\section{症例}

症例 $1 ： 62$ 歳女性, 右腎癌.

1982年12月，無症候性肉眼的血尿にて発症．前医に て CT 上肝転移を有する右腎癌と診断され，同年12月 20 日当科受診した. CT 上肝右葉後下区域に周囲が enhance され, 中心が low density の直径 $42 \mathrm{~mm}$ の腫 瘍性病変を認めた(図 1$)$. 肝転移か, 直接浸潤か鑑別 が困難であったが，病変と腎正常部分との間にくびれ が存在することより，CT 上は転移と診断された。総肝 動脈血管造影では腎腫瘍の描出を認めず, 肝右後区域 の転移性肝癌と診断された。1983年 2 月 9 日根治的右 腎摘除術を施行したが，肝病変と右腎との間に連続性

図 1 肝右葉後下区域に認める腫瘍性病変（矢印）

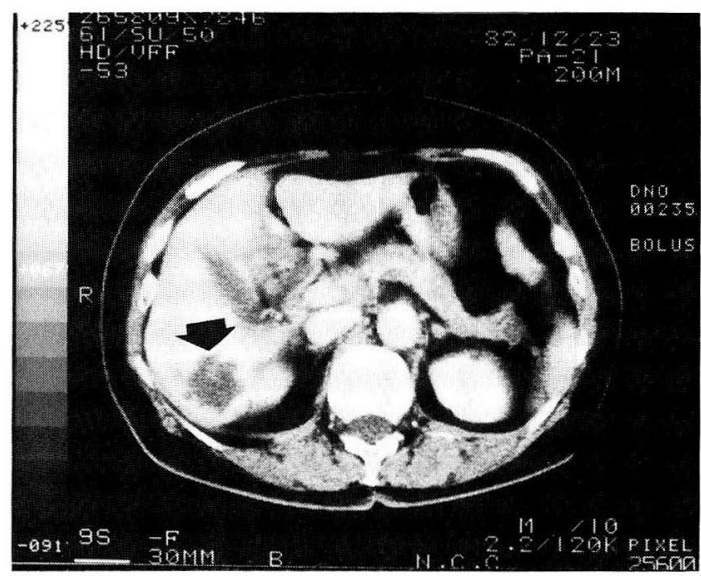

を認めず，直接浸潤は否定された。しかし，術中超音 波検査でも肝病変の性質の同定がつかず，肝部分切除 術も施行した.この肝病変は病理組織学的に肝血管腫 と診断され（図 2 ), 従って $\mathrm{pT}_{2} \mathrm{~N}_{0} \mathrm{M}_{0}$ であった。患者 は10力月後の1983年12月に骨転移を来たし，1985年 1 月27日腎癌死した。

症例 $2: 56$ 歳男性, 右腎癌.

1982年頃から無症候性肉眼的血尿を認めていたが放 置していた。やがて腹痛を伴ならに至り，1984年 3 月 3 日当科受診した.CT の所見では下大静脈に腫瘍塞 栓を認め, 肝左葉に直径 $15 \mathrm{~mm}$ の転移が疑われた。右 腎は全体が腫瘍に置換されているが, 腫瘍の辺縁は被 膜に被われ，肝への浸潤は明らかではなかった(図 3，

\section{図 2 肝の摘出標本}

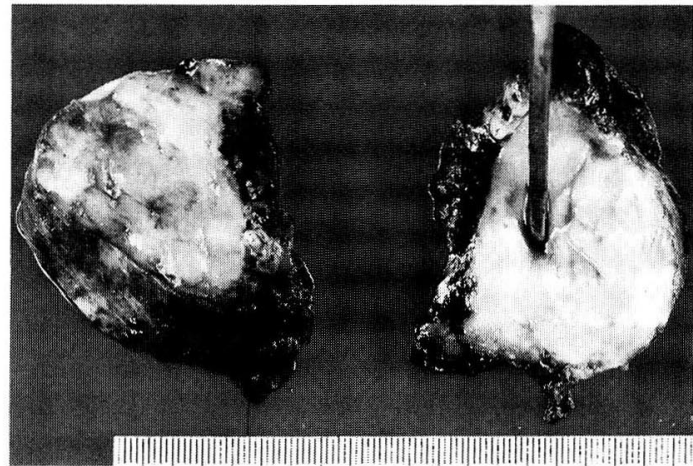

図 3 巨大な右腎腫瘍 (矢印) 肝左葉の転移巣は明ら かではない

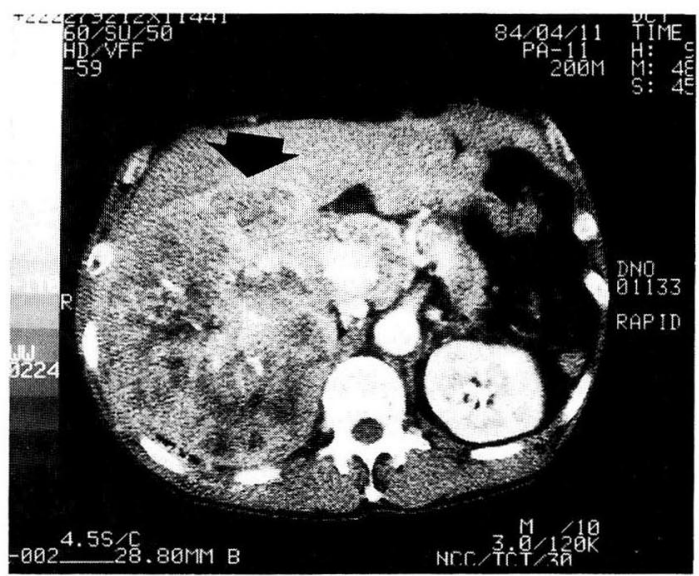


図 4 模式図 : 巨大な右腎腫瘍と下大静脈腫瘍塞栓 (斜線) 及び肝左葉の転移巣 (矢印) を示す

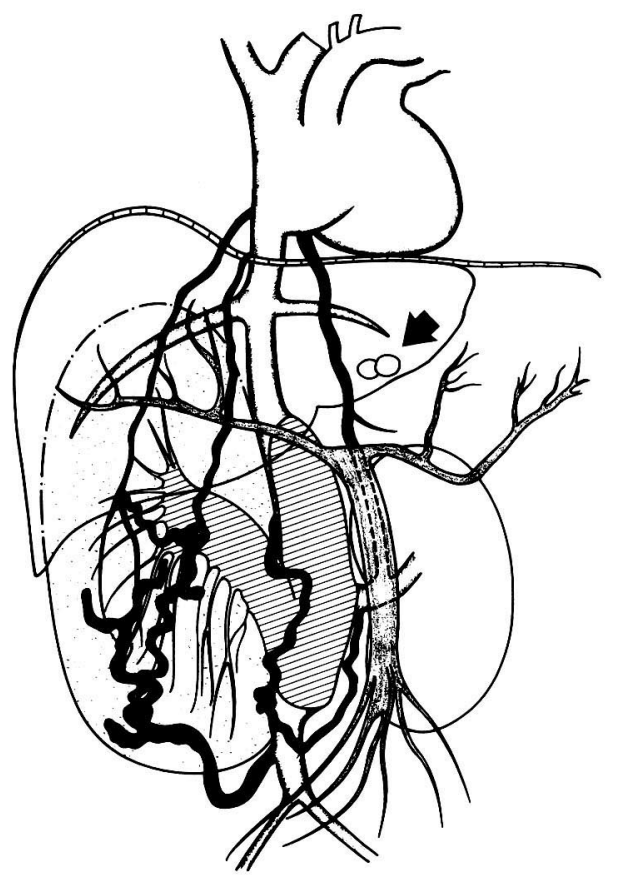

図 4 ). 右肝動脈からの血管造影では栄養血管の描出を 認めず，腫瘍の肝への浸潤はないと診断された。1984 年 4 月 20 日右腎摘除術, 下大静脈腫瘍塞栓摘除術拈よ び肝部分切除術を施行した。術中所見では腎癌は肝へ の圧排を認めるのみで直接浸潤はなかった。左葉の病 変は切除の結果病理組織学的に腎細胞癌の肝転移々診 断された。従って，腎摘除の時点で $\mathrm{p} \mathrm{T}_{3} \mathrm{~N}_{0} \mathrm{M}_{1}$ であっ た. 1 年 6 カ月後に左腎転移を来たしたため，左腎摘 除術を行ない血液透析を続けたが，肺転移，局所再発 を来たし, 腎摘除術より 3 年 3 カ月後に腎癌死した。

症例 $3: 67$ 歳男性, 左腎癌.

1987年 5 月左腎癌の診断の下に前医で根治的左腎摘 除術を施行した。術中肝に鷄卵大の腫瘤を触れたため 肝針生検を行ない，腎癌の肝転移が強く疑われた。術 後肝動脈より chemical embolizationを行なった後,

7 月 8 日当院受診した。当院での血管造影では前医で 行なわれた embolizationのため腫瘍血管が描出され ず，診断不能であった，CT では S4区域を中心に $7 \times 3$ $\mathrm{cm}$ の不整の腫瘍性病変を認め, その enhancement pattern, 内部構造からは転移性肝癌力胆管細胞癌と診 断された(図 5 ).なお, AFPは2.4ng/ml $(19.9 \mathrm{ng} / \mathrm{ml}$ 以下), CEA は $0.4 \mathrm{ng} / \mathrm{ml}(4.9 \mathrm{ng} / \mathrm{ml}$ 以下) と, いずれ
図 $5 \mathrm{~S}_{4}$ 区域を中心とする腫瘍性病変（矢印）

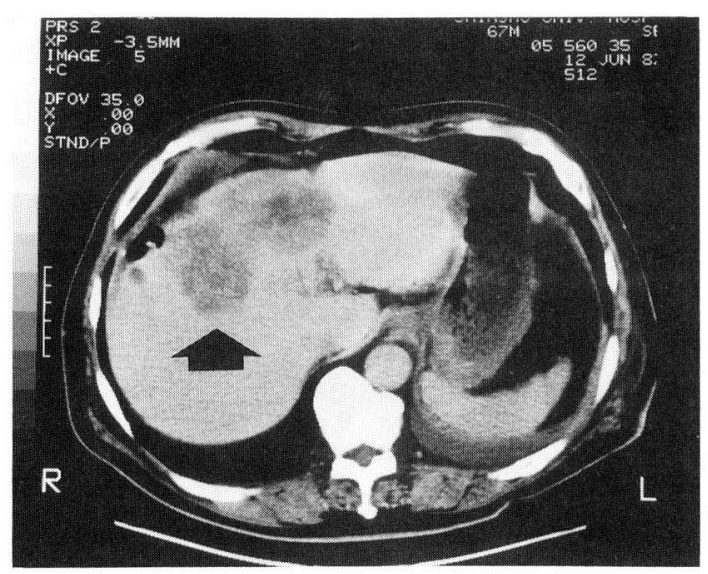

図 6 摘出標本

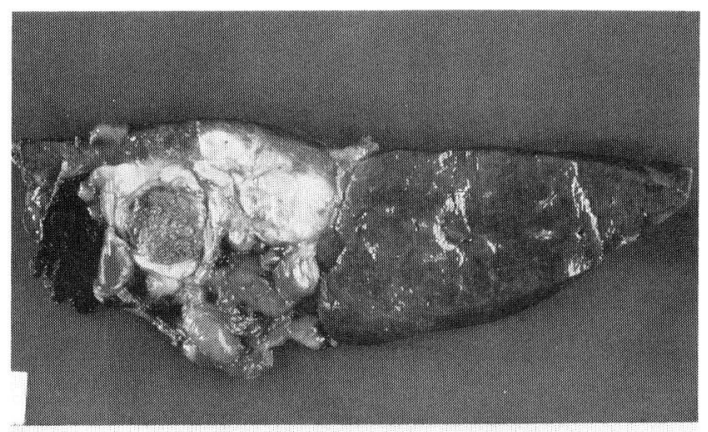

も正常域を示した. 8 月 7 日肝拡大左葉切除術を施行 し, 病理組織学的に肝細胞癌と診断された(図 6 ). す なわち, 腎細胞癌と肝細胞癌の重複癌であった。

\section{腎癌の肝転移症例の検討}

1962年12月から1988年 6 月までに, 国立がんセン タ一病院泌尿器科で経験した腎癌188例を対象とした。 全例腎摘除術を施行しており，らち37例は他院で既に 腎摘除を受けたものである。このらち，その経過中に 肝転移を来たしたのは20例である。性別は男13例, 女 7 例. 患側は右 11 例, 左 8 例, 両側 1 例である. 腎摘 除術時の年齢は23歳から70歳で, 平均49.5歳であった. 肝転移の発見時期は, 腎摘除術前に発見されたもの 1 例, 剖検により発見されたもの 4 例, 腎摘除術後の経 過観察中に発見されたもの15例である。この15例につ いて，腎摘除術から肝転移出現までの時期を検討した 結果, 腎摘除後 3 力月から 1 年 6 力月までの比較的早 期に出現する群 (以下早期群) と， 6 年以上, 最長 17 年 9 力月経って出現する群（以下晚期群）に分けられ 
た. 各症例に括ける肝転移の出現時期，様式を分析し， また摘出標本の病期および病理組織学的特徵も解析し た。

\section{結 果}

15例の経過を図 7 と図 8 に示す。腎摘除術を出発点 とし，存在する病変をすべて表わした．

早期群では, 症例 1 と症例 7 は, 腎摘除術により no evidence of disease（以下 NED）となり，それぞれ 1 年 6 カ月, 1 年 1 力月後に最初に肝転移が出現した. 次いで肺転移が出現し, 肝転移出現後それぞれ 1 年 4 力月， 4 年 9 力月生存した。他の 5 例は，腎摘除術に より NED に至らなかったか，至ってもその持続期間 が 5 カ月から 9 カ月と短かく, 皮膚転移が出現したり, 肝転移発見と同時に他臓器への転移や再発を認めてお

図 7 早期群 8 例の臨床経過

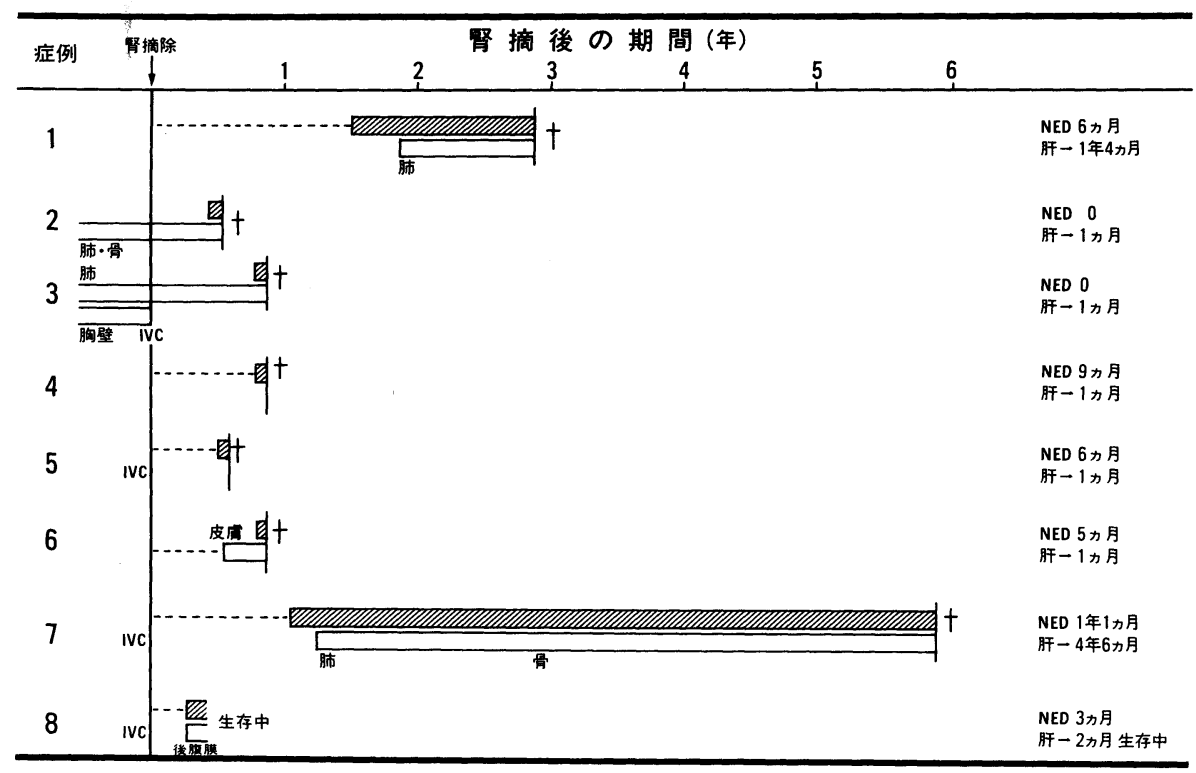

点線：NED, 斜線部：肝転移, 白線：他臓器転移, + : 死亡

図 8 晚期群 7 例の臨床経過

\begin{tabular}{l|l}
\hline 症例 \\
\hline 1
\end{tabular}


表 1 晚期群と早期群の比較

\begin{tabular}{|c|c|c|}
\hline 検即項目 & 晚期群 & 早期群 \\
\hline 男：女 & $6: 1$ & $5: 3$ \\
\hline 右: 左 & $4: 3$ & $4: 4$ \\
\hline 平均年令 & $50.0 才$ & 48.6才 \\
\hline pT分類 & $T_{2}$ 3例 $T_{3}$ 2例 & $T_{3}$ 5例 $T_{4}$ 1例 \\
\hline Robson分類 & I 3例 IIIA 1例 IV 1例 & II 1例 IIIA 1例 IIIC 1例 IV 2例 \\
\hline 細胞型 & $\begin{array}{l}\text { clear cell } 3 \text { 例 } \\
\text { clear cell>granular cell 1例 } \\
\text { granular cell } 1 \text { (例 }\end{array}$ & $\begin{array}{c}\text { clear cell } 2 \text { 例 } \\
\text { granular cell } \gg \text { clear cell } 1 \text { 例 } \\
\text { granular cell } 2 \text { 例 }\end{array}$ \\
\hline 棒築型 & solid type 1例 & $\begin{array}{l}\text { solid type } 2 \text { 例 } \\
\text { solid type }>\text { papillary type } 1 \text { 例 } \\
\text { tubular type }>\text { papillary type } 1 \text { 例 }\end{array}$ \\
\hline
\end{tabular}

り, 肝転移出現後 1 カ月以内に癌死した。尚, 症例 8 は，腎摘除術後 3 力月で肝転移および局所再発を来た し，1988年 7 月末日現在，肝転移出現後 2 力月生存中 である.

一方，晚期群は全例が腎摘除術により NED となっ ている（症例 2 は骨転移が先行しているが，まず下肢 切断を行ない，その後に施行した腎摘除術により NED となった。 またその後に認めた肺転移も肺切除 術により NED となっている。また，症例 7 は肺転移, 脳転移出現までの NED が各々11カ月，1年と短いが， その後肺転移, 肝転移とも約 3 年半 stable である). 肝 転移は，肺転移に続いて出現したもの（症例 $2 、 3$, $4 ， 5 ， 7$ ), 下大静脈腫場塞栓に続いて出現したもの (症例 3，4), 骨転移に続いて出現したもの（症例 2, 6 ）などがあり，肝転移が単独で出現することはない （症例 1 は, 肝転移発見後 1 力月で局所再発, 結腸転移 が出現して打り，肝転移発見時にはすでに存在してい たと考えるのが妥当であろう)。この群は，肝転移出現 後の生存期間が症例 2 では 3 カ月, 症例 4 では 7 カ月 と短いものの, 他は 2 年ないし 3 年 11 月と比較的長 期間生存している. 尚, 症例 6 は現在 2 年11力月生存, 症例 7 は 4 カ月生存中である。肝転移巣は早期群, 晚 期群とも全例複数である。

これらの 2 群間で病理組織学的所見, 病期に差があ るか否かを比較したのが表 1 である。早期群の症例 6 , 7 , 晚期群の症例 4，5は，他院で腎摘除を受けてい るために，詳細は不明である。症例数は少ないが，こ の比較から早期群の方が $\mathrm{pT}$ 分類でやや病期が進んで いる傾向が認められるが，他の組織学的細胞型・組織 学的構築型に関しては差は認められない. 以上より,
腎癌には腎摘後早期に肝転移を来たすものと，晚期に 発現するものがあるが，腎摘除術の時点では，このい ずれに属するかを予め知ることは現状では無理なよう である。

\section{考察}

CT scan は腎癌の術前病期診断に優れており, Jaschke ら ${ }^{1)}$ は腎癌125例について, 術前の CT 診断と摘 出腎の病理所見とを比較検討した結果，腎周囲脂肪織 への浸潤は $79 \%$ ，リンパ節転移は $87 \%$ ，腎静脈への浸 潤は $91 \%$ 下大静脈への浸潤は $97 \%$ ，そして隣接葴器へ の浸潤は96\%と，高い正診率を示し，CT scan は腎癌 の浸潤の評価の基本となると述べている。

増田 ${ }^{2)}$ は超音波断層法の術前 stage 診断について, 腎被膜への浸潤の有無とリンパ節転移の判別には困難 な場合があり，この点で超音波断層法の術前 stage 診 断には限界が見られるものの，隣接他臓器浸潤の診断 についてはCT とほぼ同様に診断できると述べてい る。まず，我々が呈示した腎癌に合併する 3 つの異な る肝病巣について議論したい。

症例 1 は当初腎癌の肝転移との診断で当科を受診し たが, CT 上直接浸潤か, 肝転移かが問題となった。最 終的には，右腎上極之腫場の間にくびれが存在するこ とにより転移と診断され，さらに総肝動脈造影で腎の 摘出を認めず周囲に淡い stain を持つ hypovascular な腫湟像を認めることから肝転移と診断された。しか しながら，本症では肝海綿状血管腫との鑑別診断がつ

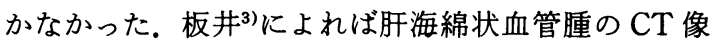
は，造影前は血液（大動脈・下大静脈）と同じ濃度で 大きな病変では内部により低い濃度の部分を伴ない境 界は鮮明である，直径 $3 \mathrm{~cm}$ 以上の場合，造影殽を急速 
注入すると辺縁近傍に点状・棒状・弧状の強い濃染部 を生じ，時間とともに周囲に拡がり，ついには血液濃 度を示した部は肝実質と同濃度となりょり強い低濃度 部を残すのみとなるのが典型的であるとされる。

Madayag $ら^{4)}$ は肝に hypervascularな病変を有した 5 例の腎癌を経験し全例を肝転移と考兄て肝も合併切 除したが，全て肝血管腫であったという。従って，肝 に hypervascular な病変を有する腎癌の場合, 他に転 移がない場合にはまず肝血管腫と考光, 肝の合併切除 の必要はないと述べている。また，肝血管腫の血管造 影像の最大のポイントは, 造影剂が注入後 $20 \sim 30$ 秒と いった長時間, 病変に残ることであるとも述べている.

症例 2 では CT 上一見肝に直接浸潤している様に見 えたが, 腫瘍が被膜で覆われていることにより直接浸 潤ではなと診断された。さらに血管造影で右肝動脈か らの栄養血管の摘出が認められないため, 肝への浸潤 はないことが確認された。

以上の 2 症例では, 直接浸潤か否かの診断はCTに 血管造影を加えることにより正しく行なわれた。この 様に右腎癌で CT 上直接浸潤が疑われる場合に，血管 造影を補助的に使うことは意義があると思われる。

症例 3 は, 前医での根治的左腎摘除術中に肝中央に 鷄卵大の腫瘤を認め, 針生検の結果肝転移が疑われた 症例である.前医で腎摘除後に embolization が行なわ れたために，当院での血管造影では腫瘍血管が描出さ れず, 肝病変の鑑別ができなかった. CT では転移性肝 癌か，胆管細胞癌であると診断された．前医での embolization がなければ，当院の CT・血管造影の診断基 準 ${ }^{5}$ によって，肝細胞癌と診断されていたかも知れな W.

腎癌の肝転移は昭和 58 年 60 年の日本病理剖検輯 報6によれば，4,345例中451例，10.4\%に見られ，肺・ 気管支転移の $17.8 \%$ に次いで多い. 当院でも 188 例中 20 例， $10.6 \%$ と，ほぼ同様の頻度である。しかし，その 発見された時期は剖検時が 4 例, 腎摘除後の経過観察 中が15例で，腎摘除を施行する時点で発見されたのは 症例 2 に供覧した 1 例のみであった。

以上より，腎摘除を行なう際に存在する肝の腫瘍性 病変は, 他臟器に病変がなければ肝転移や直接浸潤で ある可能性は低く，肝海綿状血管腫に代表される良性 腫瘍か，原発性肝癌である可能性の方が高いと思われ る。このため術前検査でどうしても良性であるとの診 断がつかない場合には, 肝病変が curative に切除可能 であるならば，腎摘除と同時に合併切除すべきである
と考光る。

次に腎摘除後に出現した15例の肝転移症例について 検討した。

早期群では 8 例中 4 例に下大静脈腫瘍塞栓を合併し ていたことが注目される。 Saito7)は1958年から1979年 までの日本病理剖検輯報をまとめ，1,828例の腎癌の 内, 腎静脈および下大静脈に腫瘍塞栓を認めた 137 例 と,認めなかった例との転移様式を比較検討している。 その結果塞栓を認めた例では, 肝・肝内リンパ節・尿 管へ転移する割合が有意に高いという。また，早期群 は腎摘除により NED とならなかった症例が 2 例, $\mathrm{NED}$ となってもその期間が 3 力月から 1 年 6 力月と 短く, 肝転移出現後 1 力月以内に癌死飞至る例が多い ことから, 早期群はいわゆる rapid growth の腎癌(あ るいは quick type $\left.{ }^{8)}\right)$ で, 肝転移の出現が末期を意味す る. 従って早期群の肝転移巣は, 積極的な治療の対象 とはなりえないと思われる。

晚期群は腎摘除術により NED となり，しかもその 期間が数年は続く傾向がある（症例 2 は他臓器転移巣 に対しても手術を施行し術後 NED となっている。 た, 症例 7 は脳転移は手術十照射により消失し, 肺転 移は再々発したものの 3 年 6 力月不变である).この様 に, 晚期群は slow growth (slow type ${ }^{7)}$ ) の腎癌とい 光よ5. 症例 6 と症例 7 は, 肝転移出現後それぞれ 2 年11力月， 3 力月生存中であるが， 7 例の肝転移出現 後の平均生存期間は21カ月であり, 早期群の11カ月に 比べて長い傾向にある。しかし, 肝転移の出現は, 腎 癌の自然経過の中での位置づけとしてはやはり末期と 考えるのが妥当であろう。

遠隔転移を有する腎癌の治療については, Maldazys ら ‘腎摘除術から転移巣出現までの NED が長いこ と, Performance status が良好であること, 転移巣が 肺実質に限局していること，原発巣を除去してあるこ と，が生存率の改善と関係あると述べている。

Golimbu ら ${ }^{10}$ は21例の転移を有する腎癌に積極的 に外科治療を行なった結果，5年以上生存した例では 5 年以内に死亡した例に比べて NED が長く, 腎摘後 2 年以上経過してから転移巣が出現した症例は， 2 年 以内に出現した例に比べて転移巣切除後の生存期間が 長いと述べている。彼らは切除した原発巣に対してそ の大きさ, 局在, 浸潤度, 細胞型, 構築型からなる prognostic factor をつくり,この factor の合計点数が 小さいこと，および転移巣を完全に切除することが転 移巣切除後の生存期間を長くすると述べている. 
里見 ${ }^{11}$ は転移巣の手術療法全体の指針として, slow growing case では積極的に手術し, rapid growing case では 2〜3 カ月化学療法などで経過をみてから， 新しい転移巣の出現のないことを確かめた後に手術を 決定すると述べている.

しかしながら，これらの報告では手術の対象となる 転移巣は, 肺・骨・軟部組織, そして脳といらのが大 部分であり，肝転移に対する治療に言及した報告は少 ない。

Khoury ${ }^{12)}$ は肝転移は腎癌の自然経過の中で最後に 出現し，その出現は予後不良を意味すると述べ，単発 性の肝転移に対しては手術も行なわれることがある が, 予後は非常に不良であると思われると述べている。

また, Neves ら ${ }^{13)}$ は1970年から1980年までの158例 の転移性腎癌の治療成績の分析の中で, 転移巣の部位 による生存率の差は認めないが，肝転移だけは例外で 予後不良であると述べて拈り，一般に肝転移は積極的 な治療の対象とはならない様である。

当院でも腎癌に対する治療法として, 現状では手術 に勝る手段はないとの観点から, 肺・骨・脳などの転 移巣に対しても積極的に手術を行なってきた。 その結 果, 蔦巣は, 1) 転移巣が curative に切除でき NED と なった症例は，そうでなかった症例に比して有意に生 存率が良いこと,2）腎摘除後の NED が長い症例の方 が, 転移巣切除後の予後が良いこと，3）転移巣切除後 の残存腫場の増悪の speed が緩徐である例や, 転移巣 切除後の NED が長い例の方が, 全体の予後が良いこ と，また，4）肝転移巣に対する治療の経験はないが, 肺・骨などの転移巣の部位による成績には差がないこ とを示した。しかし，この様な積極的治療により生存 率を向上させられる対象は限られて括り，そのため， 5）転移巣が出現してから便宜上 6 力月の経過観察期 間を扣き，この間に急激な増悪や新たな病変の出現が ない症例に対してのみ, curativeな手術が可能であれ ば積極的に治療を行ならといら方針を提示している。 また, slow growth を示す場合には, curativeにはな らなくとも, critical な転移巣のみを姑息的に手術す るとも述べている(未発表). 今回検討した 15 例の肝転 移の中にはこの条件を満たす例はなく, 積極的な治療 の対象となる肝転移は非常に少ないと考只らるが, 晚期群の中には, 今後外科的治療の対象となる症例も でてくる可能性もあると考えている.

本論文の要旨は, 第76回日本泌尿器科学会総会 (盛岡,
1988）において発表した。

\section{文献}

1) Jaschke, W., van Kaick, G., Peter, S. and Palmtag, H. : Accuracy of computed tomography in staging of kidney tumors. Acta Radiol. Diagn., 23, 593-598, 1982.

2）増井宏昭：腎細胞癌に打ける超音波断層法による 術前 Stage 診断と腫媓 Echo pattern の意義. 日泌 尿会誌，78，1675-1681，1987.

3）板井悠二, 八代直文 : 腹部 CT の系統診断. 第 1 版, 28-29, 文光堂, 東京, 1983.

4) Madayag, M.A., Bosniak, M.A., Kinkhabwala, M. and Becker, J.A.: Hemangiomas of the liver in patients with renal cell carcinoma. Radiology, 126, 391-394, 1978.

5）森山紀之，高安賢一，村松幸男，松江寛人，幕内雅 敏: 肝細胞癌の画像診断. 消化器外科, $10(6)$, 749-756, 1987.

6) 日本病理学会編。日本病理剖検輯報, 第 26 輯一 28 輯, $1984-1986$.

7) Saito, H.: Distant metastasis of renal adenocarcinoma in ptients with a tumor thrombus in the renal vein and/or vena cava. J. Urol., 127, 652-653, 1982.

8）里見佳昭：腎癌の予後に関する臨床的研究一特に 生体側の因子を中心に一, 日泌尿会誌, 64, 195-216, 1973.

9) Maldazys, J.D. and deKernion, J.B. : Prognostic factors in metastatic renal carcinoma. J. Urol., 136, 376-379, 1986.

10) Golimbu, M., Al-Askari, S., Tessler, A. and Morales, P.: Agressive treatment of metastatic renal cancer. J. Urol., 136, 805-807, 1986.

11）里見佳昭：治療成績からみた集学的治療の現状と 問題点 A. 治療成績と今後の課題, 腎細胞癌治療の 実際(町田豊平, 園田孝夫 編), 初版, 25-34, 医 薬ジャーナル社, 大阪, 1988 .

12) Khoury, S.: The treatment of metastasis from renal cell carcinoma. In Proceedings of the First Interntional Symposium on Kidney Tumors. Ed. by R. Kuss, G., Murphy, S. Khoury and J. Karr., 541-547, Alan R. Liss, New York, 1982.

13) Neves, R.J., Zincke, H. and Taylor, W.F.: Metastatic renal cell cancer and radical nephrectomy : identification of prognotic factors and patient survival. J. Urol., 139, 1173-1176, 1988.

（1988年 9 月29日受理） 